\title{
Relationship of the skin and subcutaneous tissue thickness in the tensiomyography response: a novel ultrasound observational study
}

\author{
César Calvo-Lobo ${ }^{1}$ \\ Ignacio Díez-Vega ${ }^{2}$ \\ Mónica García-Mateos ${ }^{2}$ \\ Juan José Molina-Martín ${ }^{3}$ \\ Germán Díaz-Ureña ${ }^{2}$ \\ David Rodríguez-Sanz ${ }^{2}$
}

\begin{abstract}
1. Nursing and Physical Therapy Department, Faculty of Health Sciences, Universidad de León, León, Spain 2. European University of Madrid, Faculty of Sport Sciences, Madrid, Spain
\end{abstract} 3. National Institute of Physical Education. Polytechnic University of Madrid, Madrid, Spain

http://dx.doi.org/10.1590/1806-9282.64.06.549

\section{SUMMARY}

BACKGROUND: The aim of the study was to describe and correlate the skin, subcutaneous tissue, and superficial fascia thickness assessed by ultrasonography (US) with the lumbar erector spinae muscles contractile properties evaluated by tensiomyography (TMG). METHODS: A cross-sectional descriptive study with 50 healthy participants was performed. The point of maximum lordosis in the lumbar region of the right erector spinae was evaluated by US and TMG. First, the skin, subcutaneous tissue, and superficial fascia thicknesses (cm) were assessed by US. Second, the five contractile TMG parameters were analyzed from the right erector spinae muscles belly displacement-time curves: maximal radial displacement (Dm), contraction time (Tc), sustain time (Ts), delay time (Td), and half-relaxation time (Tr). Finally, correlation analyses using Pearson ( $\mathbf{r}$ for parametric data) and Spearman ( $\mathbf{r}_{s}$ for non-parametric data) coefficients were performed.

RESULTS: A strong negative correlation was shown between Dm and subcutaneous tissue thickness $\left(r_{s}=-0.668 ; P<.001\right)$. Furthermore, moderate negative correlations were observed between Dm and skin thickness $(r=-0.329 ; P=0.020)$ as well as $\operatorname{Tr}$ and subcutaneous tissue thickness $\left(r_{s}=-0.369 ; P=0.008\right)$. The rest of the parameters did not show statistically significant correlations $(\mathrm{P}>.05)$.

CONCLUSION: Therefore, the lumbar erector spinae contractile properties during TMG assessments, especially Dm and Tr, may be widely correlated by the skin and subcutaneous tissue thickness.

KEYWORDS: Muscle contraction. Skin. Subcutaneous tissue. Ultrasonography.

ABBREVIATIONS: BMI, Body Mass Index; Dm, maximal radial displacement; $r$, Pearson correlation coefficient; $\boldsymbol{r}_{s}$, Spearman correlation coefficient; Tc; contraction time; Ts, sustain time; Td, delay time; Tr, half-relaxation time; TMG, tensiomyography; US, ultrasonography.

\section{INTRODUCTION}

The structural properties, such as deformation, thickness and hardness, of the skin, subcutaneous tissue, and superficial fascia may influence the sensory system. ${ }^{1}$ Furthermore, skin and subcutaneous tissue ultrasonography (US) features may be altered by postural changes in healthy subjects and different patient conditions, such as lymphedema.,
Tensiomyography (TMG) appears as a new technological device for evaluating the contractile properties of skeletal muscles and has recently been applied to assess musculoskeletal conditions in the lumbar erector spinae muscles. ${ }^{3}$ Nevertheless, skin thickness distributions, as well as the local hypoder$\mathrm{mal} / \mathrm{subcutaneous} \mathrm{fat,} \mathrm{and} \mathrm{fascia} \mathrm{distributions} \mathrm{may}$ 
disturb the trunk dorsum sensitivity and should be investigated through future work. ${ }^{1}$

Therefore, the aim of this study was to describe and correlate the skin, subcutaneous tissue, and superficial fascia thickness assessed by US in the erector spinae muscles contractile properties evaluated by TMG.

\section{MATERIAL AND METHODS}

\section{Study Design}

A cross-sectional descriptive study was carried out between October 2015 and December 2016, following the Strengthening the Reporting of Observational Studies in Epidemiology (STROBE) guidelines and checklist. ${ }^{4}$ Previously, the review board of the European University of Madrid (CIPI/039/15) had approved this study. Informed consent forms were signed by all participants before the beginning of the study. Furthermore, the Helsinki Declaration and ethical standards in human experimentation were considered. This research was funded and supported by the Real Madrid - European University (Ref.: 2015/09RM) and the European University of Madrid (Ref.:2015/UEM04).

\section{Sample}

A convenience sample of 50 healthy participants was recruited from the Faculty of Health, Exercise and Sport of the European University of Madrid. The inclusion criteria were healthy subjects, aged between 18 and 60 years, without bilateral non-specific pain as well as structural, neurological, visceral, or red flag conditions in the lumbopelvic region (between the subcostal line and the popliteal fossa). ${ }^{3,5}$ The exclusion criteria were prior lumbopelvic pain or treatments (within the previous 6 weeks), or medical record of neuropathy, myopathy, rheumatoid arthritis, inability to follow instructions, cognitive impairments, dysmenorrhea, pregnancy, body mass index (BMI) greater than $31 \mathrm{~kg} / \mathrm{m}^{2}$, high-level athlete self-reported activity, skin disorders, conditions (such as fracture, structural deformities or neoplasm) and surgeries in the lumbopelvic or lower limb regions., ${ }^{3,6}$

\section{Sociodemographic data}

Gender, age (y), height (cm), weight (kg), occupation (teacher, administrative staff, sports monitor, or other occupations) and BMI $\left(\mathrm{kg} / \mathrm{cm}^{2}\right)$ calculated by the Quetelet index were registered. ${ }^{7}$

\section{Outcome measurements}

Participants were placed in prone decubitus. Then, the point of maximum lordosis in the lumbar region of the right erector spinae (approximately 2 $\mathrm{cm}$ lateral to the $3^{\text {rd }}$ lumbar vertebrae) was marked on the skin with a grid of 4 perpendicular lines. Furthermore, the outcome measurement order for each point was TMG and US in order to avoid the influence of the US gel temperature on the electrical stimulus. ${ }^{3}$

First, all US evaluations and measurements were performed by the same rater, who had over 4 years of experience. A diagnostic ultrasound system (Mindray Z6; Shenzhen Mindray Bio-Medical Electronics, Nansham, 518057, China) with a $5-10.0 \mathrm{MHz}$ range linear transducer (7 L4P type; 38-mm footprint), a frequency of $10.0 \mathrm{MHz}$, a total depth imaging of $4 \mathrm{~cm}$ and the focus located with a depth of $0.5 \mathrm{~cm}$ were used to assess the resting B-mode US. The center of the probe coincided with the center of the skin marks (point of maximum lordosis) in a transversal and perpendicular position to the erector spinae muscle fibers. Skin (more superficial hyperechogenic band), subcutaneous tissue (hypoechogenic band under the skin), and erector spinae superficial fascia (hyperechogenic band under the subcutaneous tissue) US thicknesses measurements $(\mathrm{cm})$ were performed in the center of the probe footprint with the software of the US system (Fig. 1). In addition, 3 ultrasound images were captured at the same point, at the end of expiration. The mean of the 3 repeated measurements was used for the data analysis. An excellent inter- and intraexaminer US reliability has been shown in the low back region. ${ }^{1,3,6,8}$

Second, TMG was used to assess the contractile properties of erector spinae muscles. ${ }^{3}$ The five con-

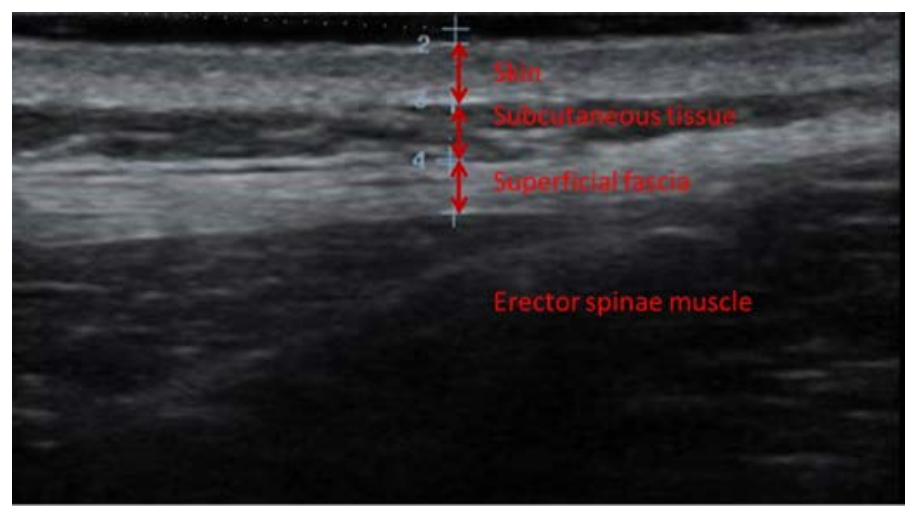

Fig. 1. US measurements of skin, subcutaneous tissue, and superficial fascia thickness. Abbreviations: US, ultrasonography. 
tractile objective parameters were analyzed from the right erector spinae muscle belly displacement-time curves: maximal radial displacement (Dm; $\mathrm{mm}$ of displacement secondary to the muscle belly electrical stimulus), contraction time (Tc; ms from $10 \%$ to 90\% of Dm in the ascending curve), sustain time (Ts; ms from $50 \%$ of Dm on both sides of the curve), delay time (Td; ms from the onset of electrical stimulus to $10 \%$ of $\mathrm{Dm}$ ), and half-relaxation time ( $\mathrm{Tr}$; ms from $90 \%$ to $50 \%$ of Dm on the descending curve). Interexaminer reliability from good to excellent was stated for these contractile parameters. ${ }^{9}$ The digital displacement transducer (GK 40, Panoptik d.o.o., Ljubljana, Slovenia) was placed perpendicular to the muscle belly on the point of maximum lordosis with an initial pressure of $1.5 \cdot 10^{-2} \mathrm{~N} \cdot \mathrm{mm}^{-2}$, coinciding with the center of the skin marks. ${ }^{10}$ Two circular self-adhesive electrodes (Model 3100C, Uni Patch, Wabasha, USA) with a diameter of $3.2 \mathrm{~cm}$ were placed symmetrically at $1.6 \mathrm{~cm}$ distal and proximal to the sensor tip (interelectrode distance of $3.2 \mathrm{~cm}$ ), longitudinally to the right erector spinae muscle belly (Fig. 2). A specialized researcher with over 4 years of TMG experience performed the measurements and data extraction. Finally, a TMG-S2 (EMF-FURLAN \& Co. d.o.o., Ljubljana, Slovenia; O-110 mA) stimulator was used to evaluate the erector spinae contractile properties at $100 \mathrm{~mA}$ of electrical current intensity during $1 \mathrm{~ms}$ (range from 0.5 to $2 \mathrm{~ms}$ ) in order to avoid post-tetanic activation. ${ }^{3,9}$

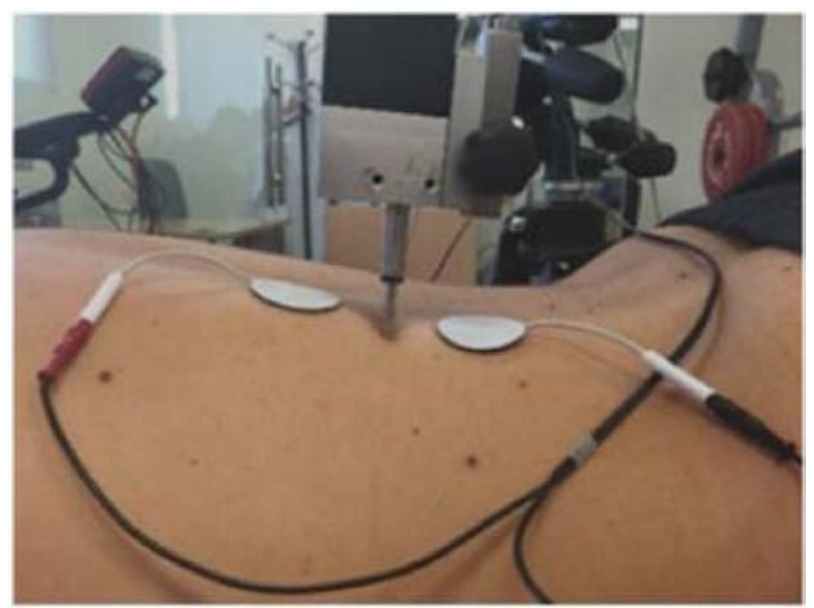

Fig. 2. TMG electrodes and digital displacement transducer placed perpendicular to the erector spinae muscle belly. Abbreviations: TMG, tensiomyography.

\section{Statistical analysis}

SPSS version 22.0 for Windows (SPSS IBM, Chicago, IL, USA) was utilized for the data analysis. First, Kolmogorov-Smirnov test was carried out to identify normal distribution (height, weight, BMI, Dm and skin thickness) or non-normal distribution (age, Td, Tc, Ts, Tr, subcutaneous tissue and superficial fascia thicknesses). Second, descriptive statistics were calculated depending on parametric (mean and standard deviation, SD) and non-parametric (median and interquartile range, IR) data. Finally, correlation analyses using Pearson ( $r$ for parametric data) and Spearman $\left(r_{\mathrm{s}}\right.$ for non-parametric data) coefficients were performed to evaluate the relationship between the outcome measurements. Correlations were interpreted as weak (0.00-0.30), moderate (0.31-0.60), or strong (0.61-1.00).,11 A 95\% confidence interval $(P<0.05)$ was considered for all data analyses.

\section{RESULTS}

A sample of 50 participants, 29 (58\%) men and 21 (42\%) women, with an age median (IR) of 36 (11.50) years as well as height, weight and BMI mean (SD) of $172.94(8.99) \mathrm{cm}, 72.11$ (15.05) kg and 23.91 (3.58) $\mathrm{kg} / \mathrm{cm}^{2}$, respectively, was recruited. Regarding the occupations, there were $33(63 \%)$ teachers, 7 (14\%) members of administrative staff, 5 (10\%) sports monitors, and 5 (10\%) with other occupations. US measurements showed a skin thickness

TABLE. CORRELATIONS BETWEEN ERECTOR SPINAE TMG CONTRACTILE PROPERTIES AND THICKNESS US MEASUREMENTS OF THE SKIN, SUBCUTANEOUS, SUPERFICIAL FASCIA AND TOTAL TISSUES.

\begin{tabular}{l|l|l|l}
$\begin{array}{l}\text { TMG } \\
\text { parameters } \\
(n=50)\end{array}$ & $\begin{array}{l}\text { Skin } \\
\text { thickness }\end{array}$ & $\begin{array}{l}\text { Subcutaneous } \\
\text { thickness }\end{array}$ & $\begin{array}{l}\text { Fascia } \\
\text { thickness }\end{array}$ \\
\hline Dm & $\begin{array}{l}r=-0.329^{*} \\
(P=.020)\end{array}$ & $\begin{array}{l}r_{\mathrm{s}}=-0.668^{\star *} \\
(P=.001)\end{array}$ & $\begin{array}{l}r_{\mathrm{s}}=-0.252 \\
(P=.077)\end{array}$ \\
\hline $\mathrm{Td}$ & $\begin{array}{l}r_{\mathrm{s}}=0.023 \\
(P=.873)\end{array}$ & $\begin{array}{l}r_{\mathrm{s}}=0.058 \\
(P=.687)\end{array}$ & $\begin{array}{l}r_{\mathrm{s}}=-0.003 \\
(P=.986)\end{array}$ \\
\hline $\mathrm{Tc}$ & $\begin{array}{l}r_{\mathrm{s}}=-0.103 \\
(P=.475)\end{array}$ & $\begin{array}{l}r_{\mathrm{s}}=-0.239 \\
(P=0.095)\end{array}$ & $\begin{array}{l}r_{\mathrm{s}}=0.009 \\
(P=0.953)\end{array}$ \\
\hline Ts & $\begin{array}{l}r_{\mathrm{s}}=-0.216 \\
(P=.133)\end{array}$ & $\begin{array}{l}r_{\mathrm{s}}=-0.240 \\
(P=.093)\end{array}$ & $\begin{array}{l}r_{\mathrm{s}}=-0.108 \\
(P=0.456)\end{array}$ \\
\hline Tr & $\begin{array}{l}r_{\mathrm{s}}=-0.123 \\
(P=0.397)\end{array}$ & $\begin{array}{l}r_{\mathrm{s}}=-0.369^{* *} \\
(P=0.008)\end{array}$ & $\begin{array}{l}r_{\mathrm{s}}=-0.017 \\
(P=0.904)\end{array}$ \\
\hline
\end{tabular}

Abbreviations: Dm, maximal radial displacement; $r$, Pearson correlation coefficient; $r$, Spearman correlation coefficient; Tc; contraction time; Ts, sustain time; Td, delay time;
Tr, half-relaxation time; TMG, tensiomyography; US, ultrasonography. ${ }^{*} P<.05$ statistically significant correlations. ${ }^{\star *} P<.001$ statistically significant correlations. 
mean (SD) of $0.29(0.04) \mathrm{cm}$ as well as subcutaneous tissue and superficial fascia thickness medians (IR) of $0.30(0.31)$ and $0.28(0.12) \mathrm{cm}$, respectively. TMG measurements showed a Dm mean (SD) of $3.65(1.98) \mathrm{mm}$ as well as Td, Tc, Ts and Tr medians (IR) of 18.07 (2.80), 16.09 (3.42), 70.59 (322.34) and $39.93(171.70) \mathrm{ms}$, respectively. As shown in the Table, a strong negative correlation was found between Dm and subcutaneous tissue thickness $\left(r_{\mathrm{s}}=-0.668 ; P<0.001\right)$. In addition, moderate negative correlations were observed between Dm and skin thickness $(r=-0.329 ; P=0.020)$, as well as $\mathrm{Tr}$ and subcutaneous tissue thickness $\left(r_{\mathrm{s}}=-0.369 ; \mathrm{P}=0.008\right)$. The other parameters did not show statistically significant correlations $(P>0.05)$.

\section{DISCUSSION}

This novel study supports the use of US during Dm and Tr TMG parameter assessment in order to evaluate the relationship of skin and subcutaneous tissue thicknesses in the evaluation of lumbar erector spinae contractile properties. Furthermore, Dm has widely been used to assess muscle stiffness, and its strong negative correlation with subcutaneous tissue thickness may have altered the TMG response. ${ }^{12,13}$ Therefore, prior TMG studies may have been influenced by the thickness of these tissues in the lumbopelvic region. ${ }^{3}$ In addition, the spine postures between extension and flexion may alter the skin thickness from $12 \%$ to $38 \%$. Consequently, such large structural deformations of the skin of the trunk dorsum should be considered in order to determine their influence in sensitivity assessments. ${ }^{1}$

\section{Limitations}

As limitations of the present study, Tr has shown insufficient reliability compared to the inter-rater reliability for the rest of TMG contractile parameters. ${ }^{9}$ Furthermore, Dm may be modified depending on each muscle group, cross-sectional muscle area, and subject, according to the morphofunctional and training characteristics. ${ }^{14}$ Finally, the small sample size and correlations in lumbopelvic conditions should be considered in future research.

\section{CONCLUSIONS}

The lumbar erector spinae contractile properties during TMG assessments, especially Dm and Tr, may be widely correlated with the skin and subcutaneous tissue thickness. Therefore, we encourage authors to consider these tissues during intersubject evaluations in future TMG research.

\section{CONFLICT OF INTEREST AND SOURCE OF FUNDING STATEMENT}

This research was funded and supported by the Real Madrid - European University (Ref.: 2015/09RM) and the European University of Madrid (Ref.:2015/UEM04).

\section{RESUMO}

CONTEXTO: O estudo foi elaborado para descrever e correlacionar a pele, o tecido subcutâneo e a espessura da fáscia superficial avaliados pelo ultrassom (EUA) com as propriedades contráteis do músculo eretor da coluna lombar avaliadas por tensiomiografia (TMG).

MÉTODOS: Foi realizado um estudo descritivo transversal com 50 participantes saudáveis. O ponto de lordose máxima na região lombar da coluna ereta direita foi avaliado pelos EUA e TMG. Primeiro, a pele, o tecido subcutâneo e as espessuras da fáscia superficial (cm) foram avaliadas pelos EUA. Em segundo lugar, os cinco parâmetros TMG contráteis foram analisados a partir das curvas de deslocamento-tempo da barriga do músculo eretor da espinha direita: deslocamento radial máximo (Dm), tempo de contração (Tc), tempo de sustentação $(T s)$, tempo de atraso ( $T d$ ) e meio tempo de relaxamento ( $T r)$. Finalmente, foram realizadas análises de correlação usando os coeficientes Pearson ( $r$ para dados paramétricos) e Spearman ( $r_{s}$ para dados não paramétricos).

RESULTADOS: Uma correlação forte negativa foi mostrada entre Dm e espessura subcutânea do tecido $\left(r_{s}=-0,668 ; P<0,001\right)$. Além disso, foram observadas correlações moderadas negativas entre Dm e espessura da pele $(r=-0,329 ; P=0,020)$, bem como a espessura subcutânea do tecido $\left(r_{s}=-0,369 ; P=0,008\right)$. O restante dos parâmetros não mostrou correlações estatisticamente significativas ( $P$ $>0,05)$.

CONCLUSÃO: Portanto, as propriedades contráteis do eretor da espinha lombar durante as avaliações TMG, especialmente Dm e Tr, podem ser amplamente correlacionadas com a pele e a espessura subcutânea do tecido.

PALAVRAS-CHAVE: Contração muscular. Pele. Tela subcutânea. Ultrassonografia.

ABREVIATURAS: IMC: índice de massa corporal; Dm: deslocamento radial máximo; $r$ : coeficiente de correlação de Pearson; $r$ : coeficiente de correlação de Spearman; Tc: tempo de contração; Ts: tempo de sustentação; Td: tempo de atraso; Tr: meio tempo de relaxamento; TMG: tensiomiografia; US: ultrassonografia. 


\section{REFERENCES}

1. Beaudette SM, Zwambag DP, Bent LR, Brown SHM. Spine postural change elicits localized skin structural deformation of the trunk dorsum in vivo. J Mech Behav Biomed Mater. 2017;67:31-9.

2. Suehiro K, Morikage N, Yamashita O, Harada T, Samura M, Takeuchi Y, et al. Skin and subcutaneous tissue ultrasonography features in breast cancer-Related Lymphedema. Ann Vasc Dis. 2016;9(4):312-6.

3. Calvo-Lobo C, Diez-Vega I, Martínez-Pascual B, Fernández-Martínez S, de la Cueva-Reguera M, Garrosa-Martín G, et al. Tensiomyography, sonoelastography, and mechanosensitivity differences between active, latent, and control low back myofascial trigger points: a cross-sectional study. Medicine (Baltimore). 2017;96(10):e6287.

4. Vandenbroucke IP, von Elm E, Altman DG, Gøtzsche PC, Mulrow CD, Pocock S), et al. Strengthening the reporting of observational studies in epidemiology (STROBE): explanation and elaboration. Int J Surg. 2014;12(12):1500-24

5. Valentin GH, Pilegaard MS, Vaegter HB, Rosendal M, Ørtenblad L, Væggemose $U$, et al. Prognostic factors for disability and sick leave in patients with subacute non-malignant pain: a systematic review of cohort studies. BMJ Open. 2016;6(1):e007616.

6. Whittaker JL, Warner MB, Stokes M. Comparison of the sonographic features of the abdominal wall muscles and connective tissues in individuals with and without lumbopelvic pain. J Orthop Sport Phys Ther. 2013;43(1):11-9.
7. Garrow JS. Quetelet index as indicator of obesity. Lancet. 1986;1(8491):1219.

8. Stokes M, Hides J, Elliott J, Kiesel K, Hodges P. Rehabilitative ultrasound imaging of the posterior paraspinal muscles. J Orthop Sport Phys Ther. 2007;37(10):581-95

9. Tous-Fajardo |, Moras G, Rodríguez-liménez S, Usach R, Doutres DM, Maffiuletti NA. Inter-rater reliability of muscle contractile property measurements using non-invasive tensiomyography. J Electromyogr Kinesiol. 2010;20(4):761-6.

10. Dahmane R, Valen i V, Knez N, Er en I. Evaluation of the ability to make non-invasive estimation of muscle contractile properties on the basis of the muscle belly response. Med Biol Eng Comput. 2001;39(1):51-5.

11. Witz K, Hinkle DE, Wiersma W, Jurs SG. Applied statistics for the behavioral sciences. J Educ Stat. 1990;15:84.

12. Pisot $R$, Narici MV, Simunic $B$, De Boer M, Seynnes $O$, Jurdana $M$, et al. Whole muscle contractile parameters and thickness loss during 35-day bed rest. Eur J Appl Physiol. 2008;104(2):409-14.

13. Ditroilo M, Hunter AM, Haslam S, De Vito G. The effectiveness of two novel techniques in establishing the mechanical and contractile responses of biceps femoris. Physiol Meas. 2011;32(8):1315-26.

14. Simunič B. Between-day reliability of a method for non-invasive estimation of muscle composition. J Electromyogr Kinesiol. 2012;22(4):52730. 